\section{A RECENT RECORD OF AstatHES BIMACULATA (FABRICIUS) (COLEOPTERA: CERAMBYCIDAE: LAMIINAE), FROM KERALA}

\author{
A. Sen ${ }^{1}$ and H.V. Ghate ${ }^{2}$ \\ 1,2 Department of Zoology, Modern College, Pune, Maharashtra \\ 411005, India \\ Email: ${ }^{2}$ hemantghate@hotmail.com (corresponding author)
} web supplement

While looking at a recent collection of Cerambycidae beetles from Kerala, we came across Astathes bimaculata (F.). It was identified using keys given by Rondon and Breuning (1970) and the species was confirmed using Gahan (1901). This species was originally described from southern India from parts of Tranquebar, Madras, Trivandrum and Bangalore. Fabricius, in 1792, had described this beetle as Cerambyx bimaculatus. This beetle was subsequently placed in the genus Astathes Newman. Genus Astathes was revised by Gahan in 1901. Since the original description was done in 1792 and subsequent reports made in 1901, we feel that its presence in southern India, even in 2003, after a period of over 200 years, merits attention. We are giving below a brief description as well as a colour photograph (Image $1^{\mathrm{w}}$ ) of the species.

Material examined: Single specimen, vi.2003, near Ponmudi road (attracted to fluorescent light), coll. Nilesh Rane, (Department of Zoology, Modern College, Pune)

Measurements: Total Length: 9.5mm; Humeral Breadth: 3.4mm; Pronotal Length: 1.6mm; Pronotal Breadth: 2.6mm; Antennal Length: $8.9 \mathrm{~mm}$

Colour yellowish, testaceous, antennae somewhat fuscous. Each elytron with a broad, transverse violaceous patch in the basal half, this patch not extending up to the suture. Metasternum laterally with a triangular fuscous patch on each side. Overall ventral colouration much paler, becoming fulvous. All body including antennae and legs covered with long, stiff, black and golden pubescence. Head with a reddish tinge.

Head finely punctate, pubescent, with distinct median groove all along the vertex, and down the front of the head. Eyes finely faceted, totally divided into two lobes (an upper and a lower) as the antennal tubercle intervenes between the two lobes, the lobe below the antennal tubercle larger than the one above. The upper lobes of the two eyes separated by about $1 \mathrm{~mm}$. Antennae shorter than body, not reaching the tip of elytra, somewhat darker, entirely pubescent, the first three antennomeres nitid, the remaining closely punctured and setose, and hence dull in appearance. First antennomere shorter than the third, the $11^{\text {th }}$ antennomere sharply pointed, and almost glabrous at the apex.

Prothorax with a short blunt tubercle on each side. The middorsal tubercle/gibbosity strongly raised, convex and rounded in the outline. On each side of this middorsal tubercle, anteriorly, is a deep pit. All these tubercles finely punctate.

Elytra yellowish, testaceous, with two moderately elevated, almost indistinct, costae on each elytron, puncturation distinct; each puncture with either yellow or black long pubescence. Elytral apex gently rounded, just about covering the abdomen. Legs overall shorter and slender. Hind femur not extending the apex of the elytra. Claws widely separated. Ventrally the most distinct feature is the metasternal process, which partly overlaps the mid coxae and rests on the end of the vertical mesosternum (this feature is the distinguishing character of the genus). Five abdominal sternites visible; the last abdominal sternite rounded.

\section{REFERENCES}

Rondon, J.A. and S. von Breuning (1970). Lamiines du Laos. Pacific Insects Monograph 24: 315 -517. Bishop Museum, Honolulu, Hawaii, USA.

Gahan, C.J. (1901). Revision of the genus Astathes Newm. and allied genera of longicorn Coleoptera. Transactions of the Royal Entomological Society of London 1901: 37-74.

\section{ACKNowledgements}

The authors would like to express their heartfelt thanks to Dr. Carolus Holzschuh, a very senior Cerambycidae expert from Austria, for confirming identity of the species (on the basis of a photo) and for providing very useful insight in our work as well as for encouragement to work on Cerambycidae. We also thank Professor D. Raychaudhuri, University of Calcutta, for kindly providing much needed literature and other help in our work on Cerambycidae. We are indebted to Ashok Captain for preparing photographs of our Cerambycidae collection. We are grateful to the authorities of Modern College for facilities.

${ }^{w}$ See Image 1 in the websupplement at www.zoosprint.org

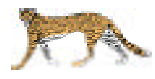

